\title{
Critical perspectives on environmental protection in non-international armed conflict: Developing the principles of distinction, proportionality and necessity
}

Smith, Tara

\section{Leiden Journal of International Law}

DOI:

$10.1017 / \mathrm{S} 0922156519000372$

Published: 01/12/2019

Peer reviewed version

Cyswllt i'r cyhoeddiad / Link to publication

Dyfyniad o'r fersiwn a gyhoeddwyd / Citation for published version (APA):

Smith, T. (2019). Critical perspectives on environmental protection in non-international armed conflict: Developing the principles of distinction, proportionality and necessity. Leiden Journal of International Law, 32(4), 759-779. https://doi.org/10.1017/S0922156519000372

\footnotetext{
Hawliau Cyffredinol / General rights

Copyright and moral rights for the publications made accessible in the public portal are retained by the authors and/or other copyright owners and it is a condition of accessing publications that users recognise and abide by the legal requirements associated with these rights.

- Users may download and print one copy of any publication from the public portal for the purpose of private study or research.

- You may not further distribute the material or use it for any profit-making activity or commercial gain

- You may freely distribute the URL identifying the publication in the public portal ?
}

Take down policy

If you believe that this document breaches copyright please contact us providing details, and we will remove access to the work immediately and investigate your claim. 


\title{
Critical Perspectives on Environmental Protection in Non-International Armed Conflict: Developing the Principles of Distinction, Proportionality and Necessity
}

\begin{abstract}
This article presents a timely and relevant critical examination of the customary international law principles of distinction, proportionality, and the doctrine of military necessity and the extent to which they can be better interpreted to protect the environment during the conduct of hostilities in non-international armed conflict. In so doing, this article contributes new perspectives to the ongoing debate on how environmental protection ought to be enhanced during non-international armed conflict. The article also suggests ways in which the International Law Commission might approach the development of draft principles based on these customary principles as part of their current programme of work.
\end{abstract}

\section{Keywords}

Non-International Armed Conflict; Environment; International Law Commission; Customary International Law

\section{Introduction}

The need to improve environmental protection in non-international armed conflict has arguably never been greater. Despite the prevalence of non-international armed conflicts in the present day ${ }^{1}$ causing damage to the environment and high-value natural resources ${ }^{2}$ such as oil, gas, timber and

\footnotetext{
1 See for example Christopher Mullins, 'Conflict Victimisation and Post-Conflict Justice 1945-2008' in M. Cherif Bassiouni (ed.) The Pursuit of International Criminal Justice: A World Study on Conflicts, Victimization, and PostConflict Justice' (Intersentia, 2010), pp. 67-107. See also the remarks of Mr. Park at the 3266th Meeting of the International Law Commission: International Law Commission, 'Provisional summary record of the 3266th meetin [sic]', Sixty-seventh session (second part), A/CN.4/SR.3266, 20 May 2016 at p. 7 and p. 10

2 See the views of Mr. El-Murtadi at the 3269th Meeting of the International Law Commission: International Law Commission, 'Provisional summary record of the 3269th meeting', Sixty-seventh session (second part), A/CN.4/SR.3269, 22 September 2015 at p. 9
} 
mineral mines, and in areas of environmental significance such as national parks and special areas of conservation, the laws of armed conflict remain dangerously out of touch with the realities of modern conflict. While specific provisions in Additional Protocol I purport to regulate the degree of environmental damage that can be caused in international armed conflict ${ }^{3}$, no such restrictions apply during non-international armed conflict. ${ }^{4}$ Despite frequent calls for the improvement of the environmental laws of non-international armed conflict, ${ }^{5}$ meaningful progress in this regard has not been made to date. ${ }^{6}$ However an unprecedented and long overdue opportunity for such reform now exists through the examination of environmental protection in times of armed conflict by the

\footnotetext{
3 Protocol Additional to the Geneva Conventions of 12 August 1949, and relating to the Protection of Victims of International Armed Conflicts (Protocol I), 8 June 1977, 1125 UNTS 3 Arts. 35(3) and 55(1). The thresholds of harm in these provisions have been heavily criticised.

${ }^{4}$ It has been suggested that the provisions of Additional Protocol I related to environmental damage arguably apply as a matter of customary international law in non-international armed conflict. See the ICRC's Customary Law Database, Rule 45 <https://ihl-databases.icrc.org/customary-ihl/eng/docs/v1_rul_rule45> (accessed 11 March 2019). However analysis of the state practice and opinio juris presented as evidence demonstrates that there is no clear intention on the part of states to extend the applicability of these provisions beyond the conflicts to which Additional Protocol I applies. For example, when drafting the Statute of the International Criminal Court, states had the opportunity to reflect such emerging customary practice in new provisions relating to war crimes. However, they decided not to create a war crime in non-international armed conflict of causing widespread, long-term or severe environmental damage. They did however affirm the applicability of this provision during in international armed conflict through Article 8(2)(b)(iv) of the Statute.
}

${ }^{5}$ United Nations Environment Programme, Protecting the Environment During Armed Conflict: An Inventory and Analysis of International Law (UNEP Post-Conflict and Disaster Management Branch 2009), p. 4. See also remarks made by the former -UN Secretary General, Ban Ki-Moon, who previously requested that states 'clarify and expand international law on environmental protection in times of war'. He further insisted that '[e]xisting legal instruments should be adapted to reflect the predominantly internal nature of today's armed conflicts.' Message of the UN Secretary-General, Ban Ki-moon on the International Day for Preventing the Exploitation of the Environment in War and Armed Conflict 6 November 2009 < http://www.un.org/zh/events/environmentconflictday/pdfs/int_law.pdf >, p. 82, (accessed 11 March 2019)

${ }^{6}$ Analysis of Articles 35(5) and 55 of Additional Protocol I, supra n. 3, Articles 35(3) and 55 which prohibit parties to international armed conflicts from causing widespread, long-term and severe environmental damage, has dominated the scholarship to date. Since no provisions comparable to those in Additional Protocol I were included in Additional Protocol II - Sylvie Junod, ‘Additional Protocol II: Scope and History' (1983-1984) 33 American University Law Review 29, 33-34 - no treaty-based laws of non-international armed conflict exist to directly prohibit environmental damage, and this may explain the analytical deficit. See also Michael Bothe, Carl Bruch, Jordan Diamond, and David Jensen, 'International Law Protecting the Environment During Armed Conflict: Gaps and Opportunities' (2010) 92 International Review of the Red Cross 569, at p. 579 noting the deficiencies in IHL as it relates to environmental protection in non-international armed conflict despite these conflicts being the most prevalent classification amongst contemporary armed conflicts. 
International Law Commission. ' Indeed, there may be 'no other international body with the knowledge, authority and terms of reference to accomplish ...[the]... task ${ }^{8}$ of finally achieving enhanced protection for the environment during armed conflict, and in particular, during noninternational armed conflict. This article makes very timely and relevant observations about the difference in the way that the customary international law principles of distinction, proportionality and military necessity apply differently during non-international armed conflict. Should the International Law Commission wish to take advantage of these differences in discussing and developing principles de lege ferend $a^{9}$ on the protection of the environment in non-international armed conflict, conflict circumstances that have long evaded clear and enforceable restrictions on the degree of environmental harm may finally be considered. ${ }^{10}$

Exploring the differences between the applicability of these three key provisions of customary international humanitarian law as between international and non-international armed conflict is important as some scholars have suggested that customary principles can only be interpreted according to the parameters set by treaty-based provisions, even if doing so lowers the degree of

\footnotetext{
7 The Statute of the International Law Commission states in Article 1(1) that it 'shall have for its object the promotion of the progressive development of international law and its codification'. Progressive development is defined in Article 15 of the Statute as 'the preparation of draft conventions on subjects which have not yet been regulated by international law or in regard to which the law has not yet been sufficiently developed in the practice of States.' Moreover the aims of the ILCs programme of work were described by the Special Rapporteur, in proposing the topic to the ILC, as amongst other things, to 'Clarify the relation between existing treaty law and new legal developments (including legal reasoning); Suggest what needs to be done to achieve a uniform and coherent system (so as to prevent the risk of fragmentation); Envisage the formulation of applicable rules and formulate principles of general international law of relevance for the topic'. Report of the International Law Commission, Sixty-third Session, A/66/10/Add.1 (2011), p. 358

${ }^{8}$ Erik Koppe, 'The Principle of Ambituity and the Prohibition against Excessive Collateral Damage to the Environment during Armed Conflict' (2013) 82 Nordic Journal of International Law 53, p. 64

9 Some members of the Commission, in discussions, appeared open to not only reflecting existing law in draft principles, but also to proposing new articles with a view to developing future law. See for example the views of Mr. Hmoud during the 3268th Meeting of the International Law Commission, supra n. 9, at p. 11

${ }^{10}$ Indeed some Commissioners have asserted the point of view that to fail to address applicable law in noninternational armed conflicts would result in the ILC's work having a minimal effect. See for example the views of Mr. Hmoud during the 3268th Meeting of the International Law Commission, supra n. 9, at p. 11
} 
environmental protection that could otherwise result. ${ }^{11}$ As non-international armed conflicts are not shackled to the problematic environmental provisions in Additional Protocol I - there are no comparative provisions in Additional Protocol II - the customary principles of distinction, proportionality and military necessity can, and should, be authoritatively interpreted in a way that provides the greatest degree of environmental protection possible in non-international armed conflict. The analysis in this article serves to advance the debate on the legal differences between environmental protection international and non-international armed conflict ${ }^{12}$ by asserting that the absence of a specific environmental provision in Additional Protocol II could actually be an advantage when exploring ways in which existing provisions could be more purposively

\footnotetext{
11 See Cordula Droege and Marie-Louise Tougas, 'The Protection of the Natural Environment in Armed Conflict Existing Rules and Need for Further Legal Protection' (2013) 82 Nordic Journal of International Law 21, discussing at p. 26 the position that protecting the environment as a civilian object would frustrate the provisions of Additional Protocol I. This argument is based on the premise that as the environment is specifically mentioned in Additional Protocol I, drafters clearly intended a different threshold of damage to apply to environmental objects regardless of their status as civilian or otherwise. However no provisions equating to those in Additional Protocol I are found in Additional Protocol II and so such an argument does not apply during non-international armed conflict. Koppe, supra n. 8, makes a similar argument at pp. $72-73$ by suggesting that as environmental provisions were enumerated in Additional Protocol I, customary law cannot be interpreted to change the threshold of harm, even if doing so could provide greater environmental protection. As there are no similar provisions in Additional Protocol II, even if one accepts these arguments, customary law can be interpreted without such restraints in non-international armed conflict to provide arguably greater environmental protection that the treaty-based provisions that apply during international armed conflict.
}

${ }^{12}$ Of the small body of scholarship has explored the issue of environmental protection during non-international armed conflict to date, international criminal law has been the dominant field of examination, though some consideration has been given to indirect protection through other treaty-based laws of non-international armed conflict. See Carl E. Bruch, 'All's Not Fair in (Civil) War: Criminal Liability for Environmental Damage in Internal Armed Conflict' (20002001) 25 Vermont Law Review 695; Aurelie Lopez, 'Criminal Liability for Environmental Damage Occurring in Times of Non-International Armed Conflict: Rights and Remedies’ (2006-2007) 18 Fordham Environmental Law Review 231; Aaron Schwabach, 'Ecocide and Genocide in Iraq: International Law, the Marsh Arabs, and Environmental Damage in Non-International Conflicts' (2004) 15 Colorado Journal of International Environmental Law and Policy 1; Theodor Meron, 'Chapter XX - Comment: Protection of the Environment During Non-International Armed Conflicts' in Richard J. Grunawalt, John E. King and Ronald S. McClain (eds), Protection of the Environment During Armed Conflict and Other Military Operations (Naval War College 1996). Throughout the schoalrship, considerations of customary international law and its potential to indirectly protect the environment during armed conflict have largely taken place either in the explicit context of international armed conflict or without specifying the differences in the way customary internayional law applies to protect the environment as between international and non-internaitonal armed conflict. This article explores the nuances in protection that are particular to non-international armed conflict, with a view to encouraging the International Law Commission, or any organisation in the future attempting to enhance and develop the law on this matter, to more fully take into account the specificities of non-international armed conflict and the applicable law in those circumstances when formulating principles either based on the lex lata, or in developing lex ferenda. 
interpreted. As states have been reluctant to develop new treaty-based law on this issue, purposively interpreting existing law might be the only feasible way to enhance and improve environmental protection in non-international armed conflict. ${ }^{13}$

The International Law Commission have already considered a number of draft principles related to environmental protection during armed conflict ${ }^{14}$, but these draft principles appear at present to be extremely conservative statements of existing law which neither explore ways in which customary international law differs as between international and non-international armed conflict ${ }^{15}$ nor the ways in which fresh interpretations of existing rules could significantly enhance environmental protection during non-international armed conflict in particular. ${ }^{16}$ For example, the draft principle that refers collectively to the customary principles discussed in this article simply

\footnotetext{
13 Although there is considerable merit to arguments which vie for the development of new legal provisions in the laws of non-international armed conflict that specifically address environmental damage, without prejudice to those views this article takes the position that more purposeful interpretations of the customary international law principles of distinction, proportionality and military necessity could result in greater limits being placed on the degree of environmental harm that may be caused during the conduct of hostilities in these circumstances without the need to overcome all diplomatic obstacles that may be foreseeable in the pursuit of amendments to treaties or the development of new treaties. See Peter Richards and Michael Schmitt, 'Mars Meets Mother Nature: Protecting the Environment During Armed Conflict' (1999) 28 Stetson Law Review 1047, at pp. 1091-1092 where the authors discuss the hesitations of the international community to develop new treaties in relation to the protection of the environment in armed conflict. Recall the attempts to develop a fifth Geneva convention. On that basis, there is a compelling case to be made for deeper consideration to be given to the customary international law principles of distinction, proportionality and military necessity by the International Law Commission when progressively developing consolidated principles to enhance the protection of the environment in non-international armed conflict under their present programme of work, and this article proceeds on that basis.
}

14 See proposals made by the Special Rapporteur in the 'Second report on the protection of the environment in relation to armed conflicts', A/CN.4/685, 28 May 2015 and amended draft principles suggested by the Drafting Committee 'Text of the draft introductory provisions and draft principles provisionally adopted so far by the Drafting Committee', A/CN.4/L.870, 22 July 2015

${ }^{15}$ Something that has been noted by members of the Commission. See the views of Mr. Forteau during the 3265th Meeting of the International Law Commission. International Law Commission, Provisional Summary Record of the 3265th Meeting, A/CN.4/SR.3265, 7 August 2015, at p. 10. See also the views of Mr. Hassouna during the 3266th Meeting of the International Law Commission, supra n. 1, at p. 5.

${ }^{16}$ Some members of the Commission have called for more detailed analysis of the laws of armed conflict in the context of this work. See Report of the International Law Commission, Sixty-seventh Session, A/70/10 (2015), 107 \ 142. Recognising the differences between these two classifications of conflict was important to some members of the Commission, and they have expressed a desire for such work to be carried out. See the aforementioned Report of the International Law Commission at p. 109 \$147. Indeed exploring environmental protection in non-international armed conflict received broad support in discussions at the Commission: International Law Commission, Third Report on the Protection of the Environment in Relation to Armed Conflicts, Sixty-Eighth Session A/CN.4/700 (2016), 7 \ 25. 
asserts that ' $[\mathrm{t}]$ he law of armed conflict, including the principles and rules on distinction, proportionality, military necessity and precautions in attack, shall be applied to the natural environment, with a view to its protection. ${ }^{, 17}$ Dynamically interpreting customary international law in a way that reflects 'emerging values cherished by society ${ }^{18}$ would ensure that the guidelines or principles developed by the International Law Commission do more than merely repeat prior attempts at conveying the law as it stands, ${ }^{19}$ attempts which have been criticised as failing to make meaningful progress towards better environmental protection during armed conflict. ${ }^{20}$ The analysis in this article therefore intentionally goes beyond a mere examination of the ways in which the customary principles of distinction, proportionality and military necessity contribute to environmental protection in non-international armed conflict; it challenges all parties engaged in the International Law Commission's programme of work to progressively interpret these key customary principles and to include such interpretation in any draft principles that are developed. ${ }^{21}$ In purposively interpreting these customary laws, the trajectory of these laws may be altered ever so slightly, and in time states may take heed of the direction provided so that a new course is chartered, one that responds to the exigencies of contemporary armed conflicts, and ultimately converging with global standards of environmental protection.

\footnotetext{
${ }^{17}$ International Law Commission, First report on protection of the environment in relation to armed conflicts by Marja Lehto, Special Rapporteur, A/CN.4/720, 20 April 2018, at p. 66

${ }^{18}$ Wil de Verwey, 'Protection of the Environment in Times of Armed Conflict: In Search of a New Legal Perspective' (1995) 8 Leiden Journal of International Law 7, at p. 22

19 For example see International Committee of the Red Cross (ICRC), Guidelines for Military Manuals and Instructions on the Protection of the Environment in Times of Armed Conflict (Geneva, 1994)

${ }^{20}$ Bothe, Bruch, Diamond, and Jensen, supra n. 6, 573

${ }^{21}$ Regarding the progressive interpretation of existing rules that apply in non-international armed conflict See for example the views of Mr. Hmoud during the 3268th Meeting of the International Law Commission, supra n. 9, at p. 11. See also the views of Mr. Vazquez-Bermudez during the 3269th Meeting of the International Law Commission, supra n. 2 , at p. 6
} 


\section{The Principle of Distinction}

The principle of distinction, which states that only military objectives can be legitimately targeted during the conduct of hostilities ${ }^{22}$, is considered 'the first test to be applied in warfare ${ }^{23}$. Under this principle, civilians and civilian objects can never be the legitimate object of an attack. If the environment is considered to be a civilian object - and scholars have argued strongly for this interpretation $^{24}$ - then it benefits from absolute protection against attack under the principle of distinction, making it unlawful to target the environment directly under any circumstances. However, protection as a civilian object may be lost if the environment, or any part of it, is defined as a military objective. ${ }^{25}$ As a military objective, the environment, or any part of it, would be a legitimate target. ${ }^{26}$ Indeed he extent to which the environment could be classified as a civilian object was the subject of substantial discussion at the International Law Commission. ${ }^{27}$ It is critical that any future consolidated principles developed go beyond merely restating the principle of distinction, but instead address some of the inherent problematic issues associated with the

\footnotetext{
22 Jann K. Kleffner, 'From 'Belligerents' to 'Fighters' and Civilians Directly Participating in Hostilities - On the Principle of Distinction in Non-International Armed Conflicts One Hundred Years After the Second Hague Peace Conference' (2007) 54 Netherlands International Law Review 315, 318

${ }^{23}$ United Nations Environment Programme, supra n. 5, 13.

24 Amongst others, Karen Hulme, 'Taking Care to Protect the Environment Against Damage: A Meaningless Obligation', (2010) 92(879) International Review of the Red Cross 675. Hulme has asserted at p. 678 that 'the recognition of the environment as a prima facie civilian object has done more to protect it than any environmentally specific rule of international humanitarian law.' See also Droege and Tougas, supra n. 11, at p. 24 highlighting the interpretation of the environment as a civilian object, either explicitly or implicitly.
}

25 The ICRC observe that the definition of a military objective applies as a matter of custom in both international and non-international armed conflicts - ICRC, Customary IHL Database < https://ihl-databases.icrc.org/customaryihl/eng/docs/v1_rul_rule8> accessed 8 March 2018, Rule 8.

${ }^{26}$ Horace B. Robertson Jr., 'The Principle of the Military Objective in the Law of Armed Conflict' [1997] Journal of Legal Studies 35, 47

27 See the Comments of Special Rapporteur summing up the debate during the $3269^{\text {th }}$ Meeting of the International Law Commission, supra n. 2, p. 10 
classification of the environment as either civilian or military in nature in non-international armed conflict.

\subsection{Classification of the Environment under the Principle of Distinction}

As the principle of distinction permits the targeting of military objectives and prohibits the targeting of civilian objects, the environment benefits from protection under this rule when it is considered to be a civilian object. It loses protection under the principle of distinction when it is considered to be a military objective. The former-Special Rapporteur to the International Law Commission proposed a draft principle reflecting this application of the law, ${ }^{28}$ though she refrained from defining the environment as a civilian object, instead opting to classify it as being 'civilian in nature'. ${ }^{29}$ The critical examination below assesses the extent to which the environment is protected by the customary principle of distinction as a civilian object, military objective and dual-use object. It is argued that any confusion created by the classification of the environment as a civilian object can be overcome with the development of guidance by the International Law Commission to support parties to a non-international armed conflict in assessing the environment correctly under this principle.

\subsubsection{Classifying the Environment as a Civilian Object}

\footnotetext{
${ }^{28}$ International Law Commission 'Second report on the protection of the environment in relation to armed conflicts', supra n. 14.

${ }^{29}$ However the proposed draft principle was not adopted by the Drafting Committee of the International Law Commission. International Law Commission, Statement of the Chairman of the Drafting Committee, Mr. Mathias $\begin{array}{llll}\text { Forteau } & 30 & \text { July } & 2015\end{array}$ $<$ http://legal.un.org/docs/?path=../ilc/documentation/english/statements/2015_dc_chairman_statement_peac.pd f\&lang=EF > (accessed 11 March 2019). The phrase 'civilian in nature' was removed and the overall draft principle altered so that the environment would not be referred to as being civilian at all. See International Law Commission, Provision summary record of the 3281st meeting, A/CN.4/SR.3281, 29 February 2016, p. 6 $<$ http://legal.un.org/docs/?path=../ilc/documentation/english/summary_records/a_cn4_sr3281.pdf\&lang=EF > (accessed 11 March 2019)
} 
The laws of armed conflict do not state that the environment is a civilian object per se, but it is commonly understood to be civilian in nature ${ }^{30}$ and the Special Rapporteur to the International Law Commission on the protection of the environment in times of armed conflict has affirmed this prima facie classification. ${ }^{31}$ There is some dispute as to whether the environment as a whole can be classified as civilian, or whether this classification can be applied only to specific objects within the environment. ${ }^{32}$ It would seem that the practice of states and international organisations to date has been to refer to the natural environment as a complete entity rather than distinguishing between parts of the environment in this regard. ${ }^{33}$ Therefore, there is a compelling argument to be made for interpreting the environment as a whole as being civilian in nature, protected in its entirety from direct attack as such. However, whether the environment is interpreted as being wholly civilian or civilian in its entirety through the sum of its parts ${ }^{34}$, the same conclusion is reached $^{35}$ : the prima facie interpretation of the environment as a civilian object.

Some members of the International Law Commission have previously suggested that the environment as a whole could not be considered civilian in its entirety by default. ${ }^{36}$ Alternative

\footnotetext{
${ }^{30}$ Hulme, supra n. 24, 678; Karen Hulme, 'Natural Environment' in Elizabeth Wilmshurst and Susan Breau (eds), Perspectives on the ICRC Study on Customary International Humanitarian Law (Cambridge University Press 2007), 209; M.N. Schmitt, C.H.B. Garraway and Y. Dinstein, The Manual on the Law of Non-International Armed Conflict (San Remo: International Institute of Humanitarian Law, March 2006), para. 4.2.4.1.

31 International Law Commission, Second Report on the Protection of the Environment in Relation to Armed Conflicts, supra n. 14, 49 \$151

32 Report of the International Law Commission, supra n. 16, 110 \154; Report of the International Law Commission on the Work of its Sixty-seventh Session, A/CN.4/689 (2015), 14 S 62. See also Droege and Tougas, supra n. 11, at p. $25-26$

33 Droege and Tougas, supra n. 11, at p. 26.

${ }^{34}$ In other words, if all environmental objects are presumed to be civilian in the first instance, then that equates to the presumption that the environment as a whole is civilian in nature.

${ }^{35}$ Droege and Tougas, supra n. 11, at p. 27

${ }^{36}$ See International Law Commission, Provisional summary record of the 3264th meeting, A/CN.4/SR.3264, 6 May 2016 p. 9 . See also : International Law Commission, supra n. 1, at p. 9
} 
proposals for draft principles in this regard have refrained from classifying the environment as a civilian object, instead asserting that '[n]o part of the natural environment may be made the object of an attack, unless and until it becomes a military objective'. ${ }^{37}$ These proposals succeeded in replacing the originally proposed draft principles, which means that there is no explicit acknowledgement that the environment is a civilian object in the International Law Commission's draft principles as they stand. ${ }^{38}$

However it is important to note that recognising the environment as being civilian in nature is not an aberration of the laws of armed conflict - and it would not preclude, as some have suggested, the movement of troops from a city to a forested area. ${ }^{39}$ If parts of the area in which armed forces are located conform to the definition of military objectives, then they may be targeted. Explicitly recognising the default position of all environmental objects as being civilian in nature is significant in terms of shaping perceptions, and it explicitly acknowledges that the targeting of environmental objects is a deliberate exception rather than a thoughtless consequence of military action during armed conflict. One of the major issues that has plagued the laws of armed conflict and their failure to adequately prohibit certain types of environmental damage in non-international armed conflict is the absence of an explicit recognition that the environment is entitled to protection. Recognising the environment as being civilian in nature is important in this regard, and also for the purposes of assessing proportionate collateral damage. If it is not explicitly acknowledged that the environment as a whole is entitled to protection against direct attack as a civilian object, then calculating what amounts to proportionate or disproportionate damage may be seriously affected.

\footnotetext{
${ }^{37}$ See International Law Commission, Provisional summary record of the 3264th meeting, supra n. 36, p. 9

38 International Law Commission, Text of the draft principles provisionally adopted in 2015 and technically revised and renumbered during the present session by the Drafting Committee, A/CN.4/L.870/Rev.1, 26 July 2016, p. 2 Draft Principle 8(3)
}

${ }^{39}$ See International Law Commission, Provisional summary record of the 3264th meeting, supra n. 36, p. 10 
Given this conclusion, it is a much more straightforward statement of the law to acknowledge the prima facie civilian status of the environment, as that would clearly establish the requirement for parties to a non-international armed conflict to refrain from attacking environmental objects without consideration, and it would affirm the requirement to evaluate specific environmental objects against the definition of military objectives if they are to be the object of an attack. Acknowledging the civilian status of the natural environment would compel parties to a noninternational armed conflict to ensure that all parts of the environment directly targeted clearly conform to the definition of military objectives. There have been some positive discussions on this point at the International Law Commission, and it would certainly be a useful clarification of the law if the Commission decided to revisit their proposed draft principles and provide determinative guidance in this regard. ${ }^{40}$

Recognising, as the Special Rapporteur to the International Law Commission has done ${ }^{41}$, that the environment is neither a non-object, nor a benign venue in which conflict takes place, means that the environment in general, as well as parts thereof, would benefit from the greatest possible protection under the principle of distinction. The any draft principle that fails to acknowledge the civilian status of the environment risks creating the impression that the environment is not protected against direct attack, a potentially regressive step which might send a message to parties engaged in non-international armed conflict that the environment is 'a valueless part of the scenery

\footnotetext{
${ }^{40}$ Indeed, some members of the Commission 'suggested that the principle [of distinction] be modified to reflect that no part of the environment be made the objective of an attack, unless and until it becomes a military objective.' International Law Commission, Third Report on the Protection of the Environment in Relation to Armed Conflicts, supra n. $16,8 \rrbracket 28$. Clarification of the circumstances in which the environment becomes a civilian object has also been called for by Droege and Tougas, supra n. 11 .

${ }^{41}$ International Law Commission, Second Report on the Protection of the Environment in Relation to Armed Conflicts, supra n. 14, $49 \$ 151$. After recognising that the laws of armed conflict suggest that civilian objects are things rather than abstract entities, they state that 'It is possible to conclude that the natural environment is civilian in nature and therefore not in itself a military objective.' Therefore the Commission appears to conclude that the environment need not be broken down into its constituent elements to benefit from protection under this principle, but may be protected in its entirety as an integrated physical entity.
} 
in which a battle takes place. ${ }^{42}$ Any future principles that are developed should therefore not merely affirm the applicability of the principle of distinction when targeting environmental objects, but should clearly state that the environment as a whole is presumed to be a civilian object as this would create clear instructions for belligerents during the conduct of hostilities in noninternational armed conflict.

A further justification for classifying the environment as a whole as being civilian in nature would be to remove any confusion regarding the concurrent application of customary and treaty-based law during non-international armed conflict. While elements of the environment are protected through Article 14 of Additional Protocol II, ${ }^{43}$ for example, environmental protection as a whole is stronger in non-international armed conflict under the customary principle of distinction. Article 14 limits protection to those objects which, if targeted and destroyed, would cause starvation amongst the civilian population. There is no such qualification or limitation attached to the protection afforded to civilian objects under the customary principle of distinction. In the absence of a clear statement acknowledging the classification of the envurinment as a civilian objects, belligerents in non-international armed conflict may prefer to adhere to the treaty-based provision as it shields fewer environmental objects from direct attack. Defining the environment as a whole as civilian in nature, and affirming the concurrent and compulsory application of the customary principle of distinction would reduce the risk that only specific environmental objects essential to the survival of the civilian population would be viewed as protected objects during the conduct of hostilities. While a principle on the relationship between the principle of distinction and the environment has been proposed to the International Law Commission ${ }^{44}$, it could go much further

\footnotetext{
42 Hulme, supra n. 24, 678

43 Protocol Additional to the Geneva Conventions of 12 August 1949, and relating to the Protection of Victims of Non-International Armed Conflicts (Protocol II), 8 June 1977, 1125 UNTS 609, Art. 14

44 International Law Commission, Text of the Draft Introductory Provisions and Draft Principles Provisionally Adopted So Far by the Drafting Committee, supra n. 14, Draft Principle II-1(3)
} 
towards clarifying the applicable law to enhance environmental protection in non-international armed conflict.

\subsubsection{Classifying the Environment as a Military Objective}

Military objectives generally include objects that contribute to 'the enemy's war-fighting or warsustaining capability ${ }^{45}$ and it is not difficult to imagine a multitude of circumstances in which the environment could be viewed as such during non-international armed conflict: from fuelling and funding the conflict, to providing camouflage and sustenance, it is very difficult to completely divorce armed conflict from its surrounding environment. Under the principle of distinction, the environment can lose its protection as a civilian object only if by reason of its 'nature, location, purpose $^{36}$ it makes an 'effective contribution to military action', and if its 'partial or total destruction, capture or neutralization, in the circumstances ruling at the time, offers a definite military advantage'. ${ }^{48}$ To the extent that the natural environmental satisfies this criteria, it is no longer considered to be a civilian object, but instead a military objective which can be lawfully targeted during the conduct of hostilities. The ICRC recognises that the definition of military objectives is 'a wide one, which includes areas of land, objects screening other military objectives and war-supporting economic facilities. ${ }^{49}$ While elements of the environment do not automatically or intrinsically conform to the definition of military objectives, their use by parties to an armed

45 The Commander's Handbook on the Law of Naval Operations, Edition July 2007, <http://www.jag.navy.mil/documents/NWP_1-14M_Commanders_Handbook.pdf> accessed 8 March 2018, section 8.2

${ }^{46}$ Additional Protocol I, supra n. 3, Art 52, a rule which has become part of customary international law applicable in both international and non-international armed conflict. See also Michael Bothe, Karl J. Partsch and Waldemar A. Solf, New Rules for Victims of Armed Conflicts: Commentary on the Two 1977 Protocols Additional to the Geneva Conventions of 1949 (Martinus Nijhoff Publishers 1982), 324

${ }^{47}$ Additional Protocol I, supra n. 3, Art 52

48 Ibid.

49 ICRC, Customary IHL Database < https://ihl-databases.icrc.org/customary-ihl/eng/docs/v1_rul_rule8> accessed 8 March 2018, Rule 8 
conflict means that they can become legitimate targets. ${ }^{50}$ Therefore classifying the environment as a military objective is not, in many circumstances, a conceptual stretch of the imagination.

In the context of contemporary non-international armed conflicts which have a particularly strong connection to the exploitation of natural resources, determining the extent to which the environment, or elements of it, satisfy the definition for military objectives, is a pressing issue which needs to be addressed in any principles that are developed to enhance environmental protection in these circumstances. Natural resources - valuable, precious and vulnerable as they are - may be so closely connected to the conflict that classifying them as military objectives may not be a challenging exercise. Although objects need to make a contribution to military action to be classified as a military objective, such that attacking them will result in military advantage $e^{51}$, in many non-international armed conflicts that involve natural resource exploitation, the lines between contributing to military action and contributing merely to the 'war-sustaining capability'52 of a party engaged in the armed conflict will be blurred. It has been argued that revenue-generating natural resources which are exploited by an armed group to support their engagement in a conflict do not make a sufficiently direct and effective contribution to military action ${ }^{53}$, however the contrary could certainly be argued with equal legal weight. For example, if a non-state armed group took control of an oil refinery, and if the profits from the sale of that oil are the only source of funding supporting the group's conflict effort, then targeting that refinery could result in a definite military advantage. The fact that there is an arguable point in this regard means that environmental

\footnotetext{
${ }^{50}$ Droege and Tougas, supra n. 11, at p. 27-28

${ }^{51}$ Ibid. at p. 29

52 Ibid.

${ }^{53}$ Ibid.
} 
objects may be too easily classified as military objectives ${ }^{54}$, and the protection against attack that they benefit from as civilian objects decreases significantly as a result.

Examples of the way in which environmental objects can be construed as military objectives abound throughout the history of non-international armed conflict. During the American Civil War, for instance, the destruction of cotton fields was not considered to be a breach of the principle of distinction: cotton was the Confederacy's primary export at the time, the sale of which funded the purchase of Confederate supplies and weapons, and so it was considered to be a military objective which could be lawfully targeted on that basis. ${ }^{55}$ Similar issues arise frequently in contemporary non-international armed conflicts: the exploitation of natural resources has been recognised by the UN Security Council as a major factor in funding and perpetuating armed conflict in the Central African Republic ${ }^{56}$ and as a result such resources may be classified as military objectives that can be directly and legitimately attacked during the conduct of hostilities. ${ }^{57}$ It is argued here that any principles that are developed by the International Law Commission could compel parties to an armed conflict to construe the definition of military objectives as narrowly as possible when it comes to environmental objects, particularly elements of the environment that are at risk of additional harm through exploitation as a result of the conflict.

There is a danger that classifying the environment as a whole as a civilian object might encourage belligerents to use civilian environmental objects as shields against attack, much in the same way

\footnotetext{
${ }^{54}$ Bothe, Bruch, Diamond, and Jensen, supra n. 6, pp. 576-577

${ }^{55}$ Robertson, supra n. 26, at footnote 15

${ }^{56}$ UN Security Resolution 2121, S/Res/2121 (2013); UN Security Resolution 2127, S/Res/2127 (2013)

${ }^{57}$ United Nations Environment Programme, supra n. 5, 13
} 
that human shields are used.$^{58}$ However unlike the law relating to human shields ${ }^{59}$ the use of civilian environmental objects as a shield against attack would merely result in those objects being reclassified as military objectives which could be legitimately targeted in attack. ${ }^{60}$ In contemporary non-international armed conflict, '[i]nsurgents often use tropical forests as home bases and hiding grounds; counter-insurgency forces often respond by slashing and burning forests and by polluting rivers, viewing both as legitimate theatres of operations. ${ }^{61}$ These kinds of actions undermine the protection that the environment, in particular valuable or vulnerable environmental locations, need to benefit from during non-international armed conflict. If military targets are deliberately located in areas special areas of protection or conservation, for example, the nature of the surrounding environment may change from civilian to military, thereby removing the absolute protection against attack that would otherwise apply to civilian objects through the principle of distinction. The International Law Commission should retain draft principles already proposed in this regard ${ }^{62}$ making the use of valuable or vulnerable environmental civilian objects by belligerents in non-

\footnotetext{
${ }^{58}$ Gabriel Swiney, 'Saving Lives: The Principle of Distinction and the Realities of Modern War' (2005) 39 International Lawyer 733, 751. Swiney discussed the ICRC's assertion that dual-use targets should be prima facie treated as civilian and as such, he argued that this would more than likely create incentives for belligerents to use human shields and deliberately mix military and civilian objects.
}

59 ICRC Customary IHL Database $<$ https://ihl-databases.icrc.org/customaryihl/eng/docs/v1_cha_chapter32_rule97> accessed 18 September 2018, Rule 97

${ }^{60}$ Droege and Tougas, supra n. 11, arguing at p. 28 that classifying the environmental area in which armed forces are located as a military objective would not accord with existing practice under international humanitarian law. Therefore, automatically classifying the environment as a military objective simply on the basis of location would apply the definition of military objectives too loosely. Examples cited include identifying cities in which armed forces are located as military objectives - the entire city would not be considered a military objective, only the very specific areas in which armed forces are location, and even at that, the classification as military objective would most likely apply through the use of the area, rather than the location.

${ }^{61}$ De Jong, Donovan and Abe (eds), Extreme Conflict and Tropical Forests; see also Mark A. Drumbl, 'Waging War Against the World: The Need to Move from War Crimes to Environmental Crimes' in Jay E. Austin and Carl E. Bruch (eds), The Environmental Consequences of War: Legal, Economic, and Scientific Perspectives (Cambridge University Press 2000), 631

62 International Law Commission, Text of the draft principles provisionally adopted in 2015 and technically revised and renumbered during the present session by the Drafting Committee, supra n. 38, p. 2 Draft Principle 8(3) 
international armed conflict a breach of the principle of distinction, much in the same way that the use of human shields is prohibited.

\subsubsection{Classifying the Environment as a Dual-Use Object}

It is 'beyond dispute ${ }^{63}$ that those engaged in non-international armed conflict are required to make the primary distinction between civilians and civilian objects on the one hand, and military objectives on the other, before embarking upon any method or means of warfare likely to result in harm. ${ }^{64}$ The law indicates clearly that objects can only have a single status at any given time, either civilian or military, never both concurrently. Yet the natural environment will most often serve both military and civilian uses simultaneously, and this makes the determination of the civilian or military status of environmental objects one of the most difficult applications of the principle of distinction in contemporary non-international armed conflict.

As a dual-use object, strictly separating the areas or times of civilian use from military use when applying the principle of distinction on the battlefield in non-international armed conflict could prove extremely problematic. ${ }^{65}$ The ICRC have concluded, from a review of state practice and opinio juris that the law is not clear on what to do where there is doubt as to an object's civilian or military status. ${ }^{66}$ While there is some, albeit inadequate, guidance in the treaty-based laws of international armed conflict, no such provisions exist that apply during non-international armed conflict. ${ }^{67}$ As a dual-use object, therefore, the environment is at risk of significant harm.

\footnotetext{
${ }^{63}$ Kleffner, supra n. 22, 308

${ }^{64}$ Kleffner, supra n. 22, 318

${ }^{65}$ Swiney, supra n. 58, 751

66 ICRC Customary IHL Database < https://ihl-databases.icrc.org/customary-ihl/eng/docs/v1_rul_rule10> accessed 18 September 2018, Rule 10

${ }^{67}$ Ibid.
} 
The International Law Commission are in a strong position to propose principles that clarify the law $^{68}$ and provide guidance to belligerents in order to improve environmental protection in noninternational armed conflict. Such guidance could take many forms: for example, the International Law Commission could suggest that special areas of conservation including areas that contribute to the solution of global problems such as climate change, food security, or water security, and areas of cultural significance, should always be considered civilian objects. ${ }^{69}$ This would remove any element of subjective judgement where such areas were concerned. ${ }^{70}$ If complimented by a principle which makes using irrefutably civilian environmental objects as shields against attack a breach of the principle of distinction, greater protection would be achieved for particularly important and vulnerable environmental locations than currently exists under the customary laws of armed conflict, and that enhanced protection would be directed to parts of the environment that perhaps could be argued need protecting the most.

\subsection{Indiscriminate Attacks}

The principle of distinction is sometimes referred to as the principle of discrimination. In this regard, the International Criminal Tribunal for the former Yugoslavia (ICTY) has held that 'attacks, even when they are directed against legitimate military targets, are unlawful if conducted

68 Indeed including clarifications with draft principles has been suggested by members of the Commission. See the comments of Mr. Hmoud during the 3268th Meeting of the International Law Commission, supra n. 9, at p. 13

${ }^{69}$ See Richard G. Tarasofsky, 'Protecting Specially Important Areas During International Armed Conflict: A Critique of the IUCN Draft Convention on the Prohibition of Hostile Military Activities in Protected Areas' in Jay E. Austin and Carl E. Bruch (eds), The Environmental Consequences of War: Legal, Economic, and Scientific Perspectives (Cambridge University Press 2000), 568. See also the recommendations made by Droege and Tougas, supra n. 11, at p. 43 which have been drawn from propoals by the IUCN, UNEP and the ICRC and which support the establishment of special areas of environmental protection which cannot be damaged in any context during armed conflict. See also Bothe, Bruch, Diamond, and Jensen, supra n. 6, at p. 577 arguing for the exclusion of military from sensitive environmental areas. Bothe et al suggested that an international organisation, such as the UN, should call upon parties to conclude legally binding agreement in this regard. It is submitted here in this article that perhaps the International Law Commission could be that international body, given the focus of its work.

70 Richards and Schmitt, supra n. 13, argue at p. 1081 that 'subjectivity clouds determinations of what is protected, and what is not'. 
using indiscriminate means or methods of warfare, or in such a way as to cause indiscriminate damage to civilians ${ }^{71}$ or civilian objects. In other words, belligerents should not use methods or means of warfare that cannot distinguish between military objectives and civilian objects, and this includes environmental civilian objects. The prohibition against indiscriminate attacks applies as a matter of custom in non-international armed conflict ${ }^{72}$ and the application of this prohibition to environmental civilian objects could be emphasised in any future principles that are developed by the international community, as at present it does not feature in the draft principles that are under consideration at the International Law Commission. ${ }^{73}$

\subsection{Conclusion to the Principle of Distinction}

The principle of distinction prohibits damage to the environment in non-international armed conflict when the environment is classified as a civilian object. It does not prohibit damage when the environment is classified as a military objective. Suggestions to strengthen the way in which the principle of distinction can better protect the environment have previously been made, and they assert, in relation to the ICRC's Customary Law Study, that the customary rule should state that ' $[\mathrm{t}]$ he natural environment may not be attacked, unless it is a military objective and only to the extent that it is a military objective ${ }^{974}$. While such suggestions echo the present draft principles that have been proposed by the International Law Commission, and are without question a helpful starting point, the real difficulties in applying the principle of distinction to enhance environmental protection relate to determining the civilian or military status of the environment: that is not always

\footnotetext{
${ }^{71}$ Prosecutor v Kupreškić et al ICTY Judgement, Case No IT-95-16-T, 14 January 2000 International Criminal Tribunal for the former Yugoslavia, para 524

72 ICRC, Customary IHL Database < https://ihl-databases.icrc.org/customary-ihl/eng/docs/v1_rul_rule11> accessed 8 March 2018, Rule 11

${ }^{73}$ International Law Commission, Second Report on the Protection of the Environment in Relation to Armed Conflicts, supra n. 14, 49 \ 151

${ }^{74}$ Hulme, supra n. 30, p. 211
} 
a straightforward or simple exercise. Given the strong connection between the environment, natural resources and contemporary non-international armed conflict, a more detailed examination of the way in which the environment changes from civilian to military classification during these circumstances is fully warranted. Where the environment is considered to be a dual-use object, it is at risk of significant harm, and there should be a presumption in favour of recognising the environment, or certain elements of it, as being irrefutably civilian in nature to protect particularly vulnerable or important parts of the environment from direct and indiscriminate harm during noninternational armed conflict. Principles developed by the International Law Commission could also usefully emphasise the prohibition against indiscriminate attacks to give belligerent parties a clear, accurate and complete statement of the law.

\section{The Principle of Proportionality}

The customary principle of proportionality is another foundational concept within the laws of armed conflict, ${ }^{75}$ and it was referred to in draft principles proposed by the Special Rapporteur to the International Law Commission. ${ }^{76}$ Proportionality recognises that there is a balance to be struck between the value of a military objective and the incidental damage caused in launching an attack

\footnotetext{
${ }^{75} \mathrm{It}$ is not a universally held point of view that the principle of proportionality applies in non-international armed conflict as a matter of custom. See A.P.V. Rogers, 'The Principle of Proportionality' in Howard M. Hensel (ed), The Legitimate Use of Military Force: The Just War Tradition and the Customary Law of Armed Conflict (Ashgate Publishing Limited 2008), 190. However there is a sufficient body of evidence to strongly support the conclusion that the principle of proportionality does apply in non-international armed conflict as a matter of custom. See ICRC, Customary IHL Database < https://ihl-databases.icrc.org/customary-ihl/eng/docs/v1_rul_rule14> accessed 8 March 2018; ICRC, Customary IHL Database <https://ihl-databases.icrc.org/customary-ihl/eng/docs/v2_rul_rule14> accessed 8 March 2018, Rule 14

76 International Law Commission, Second Report on the Protection of the Environment in Relation to Armed Conflicts, supra n. 14, p. 52, Draft Principle 2: 'During an armed conflict, fundamental principles and rules of international humanitarian law, including the principles of precautions in attack, distinction and proportionality and the rules on military necessity, shall be applied in a manner so as to enhance the strongest possible protection of the environment.' Also see at p. 53 Draft Principle 3 'Environmental considerations must be taken into account when assessing what is necessary and proportionate in the pursuit of lawful military objectives.'
} 
upon that objective. ${ }^{77}$ In striking the balance between proportionate use of force and proportionate collateral damage, the International Court of Justice has stated that ' $\mathrm{r}$ ] espect for the environment is one of the elements that go to assessing whether an action is in conformity with the principles of necessity and proportionality. ${ }^{78}$ The ICRC have found evidence of state practice and opinio juris which prohibits disproportionate environmental damage when attacks are launched against military objectives during non-international armed conflict. ${ }^{79}$ As such, there is strong evidence to support the assertion that belligerents are legally required to take damage to environmental civilian objects into account when planning proportionate attacks in non-international armed conflict. ${ }^{80}$ The International Law Commission is presently considering a draft principle which suggests that proportionality should be applied to achieve the strongest possible protection, ${ }^{81}$ but there are many interpretive issues which prevent this goal from being realised in any given conflict. Indeed, the argument that "little law exists to explain how this should operate in practice ${ }^{82}$ remains valid. The International Law Commission could develop ambitious interpretations of the principle which both affirm its application to environmental collateral damage and address the issues that presently

\footnotetext{
77 Antonio Cassese, International Law (2nd edn, Oxford University Press 2005), 417. See also Lauterpacht as quoted in Rogers, supra n. 75, 198 - non-combatants 'were not immune from collateral damage but a just balance had to be maintained between the military advantage and the injury to non-combatants.'. See also Richards and Schmitt, supra n. 13 , at p. 1082.

${ }^{78}$ International Court of Justice, Legality of the Threat or Use of Nuclear Weapons, Advisory Opinion, 1996 ICJ Reports 226, 8 July $1996, \$ 30$ and $\$ 33$

79 ICRC, Customary IHL Database, Rule 43(C) <https://ihl-databases.icrc.org/customaryihl/eng/docs/v1_rul_rule43> accessed 8 March 2018.

${ }^{80}$ Richard Desgagné, 'The Prevention of Environmental Damage in Time of Armed Conflict: Proportionality and Precautionary Measures' (2000) 3 Yearbook of International Humanitarian Law 109, 116.

${ }^{81}$ Report of the International Law Commission, supra n. 16, p. 104, Principle 2. Although there seems to be some disagreement within the Commission regarding this principle - some members regard the draft principle as too broad and ambitious, others view is as being too specific: Report of the International Law Commission on the Work of its Sixty-seventh Session, supra n. 32, 14 \63
}

${ }^{82}$ See Dieter Fleck, "The Protection of the Environment in Armed Conflict: Legal Obligations in the Absence of Specific Rules', (2013) 82 Nordic Journal of International Law 7, at p. 10 
inhibit the full extent of the environmental protection that can be achieved through better proportionality assessments. ${ }^{83}$

The principle of proportionality requires inadvertent harm to civilians and civilian objects to be balanced against the advantage anticipated by attacking a military objective. ${ }^{84}$ For example, if a military objective is located in an environment which is presumed to be a prima facie civilian object, then although the environment cannot be directly targeted, a certain degree of collateral damage is permitted when the military objective is attacked - the principle of proportionality regulates the extent of the damage that can be considered lawful in those circumstances.

To respect the principle of proportionality, belligerents are required to weigh the military advantage that they anticipate to gain from an attack against the expected damage that will be caused as a result. The Office of the Prosecutor at the ICTY observed that 'military objectives should not be targeted if the attack is likely to cause collateral environmental damage which would be excessive in relation to the direct military advantage which the attack would be expected to produce. ${ }^{85}$ Illustrating this rule, the United Nations Environment Programme assert that the destruction of 'an entire village or burning an entire forest to reach a single minor target' ${ }^{86}$ would not be proportionate collateral damage when weighed against the military advantaged gained by the attack. The evaluation of permissible levels of collateral damaged is based on both the direct military

\footnotetext{
${ }^{83}$ Indeed some members of the Commission have indicated that it would be important for the International Law Commission to elaborate on the way in which the principle of proportionality ought to be applied to the environment. See the views of Mr. Hmoud as expressed at the 3268th Meeting of the International Law Commission, supra n. 9, at p. 13

${ }^{84}$ Karen Hulme, War Torn Environment: Interpreting the Legal Threshold (Martinus Nijhoff Publishers 2004), 126

${ }^{85}$ ICTY, Final Report to the Prosecutor by the Committee Established to Review the NATO Bombing Campaign Against the Federal Republic of Yugoslavia, $2000<$ http://www.icty.org/en/press/final-report-prosecutorcommittee-established-review-nato-bombing-campaign-against-federal> accessed 8 March 2018

${ }^{86}$ United Nations Environment Programme, supra n. 5, 13
} 
advantage $^{87}$ expected from the attack and the value of the environmental civilian object. The greater the value of the military objective, the greater the extent of the proportionate collateral damage that can be caused; the higher the value of the environmental civilian object, the lesser the collateral damage that may be permitted. ${ }^{88}$

\subsection{Valuing the Environment Correctly in Proportionality Assessments}

There is an inherent vagueness within the principle of proportionality that makes calculating proportionate environment damage 'easier to proclaim than to implement in practice. ${ }^{89}$ It is not immediately clear from the principle how exactly military targets or environmental civilian objects ought to be valued when assessing the anticipated proportionality of an attack ${ }^{90}$ Moreover, value judgements may change over time. ${ }^{91}$ The optimum way to conduct a balancing exercise under the

\footnotetext{
${ }^{87}$ Military advantage essentially means that the act must have positive military utility or purpose. In terms of what counts as being concrete and direct military advantage, the ICRC Customary IHL Database provides useful explanations. The ICRC Customary Law Study helpfully highlights that 'Upon ratification of Additional Protocol I, Australia and New Zealand stated that they interpreted the term "concrete and direct military advantage anticipated" as meaning that there is a bona fide expectation that the attack would make a relevant and proportional contribution to the objective of the military attack involved. According to the Commentary on the Additional Protocols, the expression "concrete and direct" military advantage was used in order to indicate that the advantage must be "substantial and relatively close, and that advantages which are hardly perceptible and those which would only appear in the long term should be disregarded"' ICRC, Customary IHL Database < https://ihl-databases.icrc.org/customaryihl/eng/docs/v1_rul_rule14> accessed 8 March 2018; In addition, Bothe at al observe that 'The term military advantage involves a variety of considerations, including the security of the attacking force. Whether a definite military advantage would result from an attack must be judged in the context of the military advantage anticipated from the specific military operation of which the attack is a part considered as a whole, and not only from isolated or particular parts of that operation. It is not necessary that the contribution made by the object to the Party attacked be related to the advantage anticipated by the attacker from the destruction, capture or neutralization of the object.' Bothe, Partsch and Solf, supra n. 46, 324
}

${ }^{88}$ Hulme, fn. 84, 126

${ }^{89}$ Desgagné, fn. 80, 116

${ }^{90}$ Robert Perry Barnidge Jr, 'The Principle of Proportionality Under International Humanitarian Law and Operation Cast Lead' in William C. Banks (ed), New Battlefields/Old Laws (Columbia University Press 2011), 276

${ }^{91}$ Though it may be argued that contemporary assessments of the public conscience, as represented by the exponential growth in international environmental law, demonstrate a strong trend in favour of valuing environmental integrity quite highly. For early scholarly discussions on this point see Michael Bothe 'The Protection of the Environment in Times of Armed Conflict: Legal Rules, Uncertainty, Deficiencies and Public Developments', (1991) 34 German Yearbook of International Law 54, at p. 56. See also Richards and Schmitt, supra n. 13, at pp. 1084-1085 arguing that environmental damage barely registered as a point of conflict analysis in the 1950s, but that it is the focus of substantial 
principle of proportionality is to compare like values with like. ${ }^{92}$ However this is not always possible when military objectives and environmental civilian objects are being compared ${ }^{93}$ since 'military, humanitarian and environmental values" ${ }^{\prime 94}$ are different from each other and not directly comparable. ${ }^{5}$ For example, would attacking enemy headquarters to end a conflict justify the destruction of an endangered species whose extinction is all but guaranteed through the collateral damage expected as a result of the attack? What if the environmental value was more abstract for example, the benefit of upholding ecosystem integrity - how could that be weighed accurately against the same military objective? There is certainly substantial dissonance between military and environmental values ${ }^{96}$ that has not yet been fully reconciled in theory or practice to date.

Valuing the environment correctly and objectively is a difficult task, even without the concurrent requirement to value a military objective, and it is likely an element of the proportionality calculation that state armed forces and non-state armed groups alike are ill-equipped to carry out competently during non-international armed conflict. While in best case scenarios environmental impact assessments may be conducted during the planning phases of an attack ${ }^{97}$, anticipating the environmental consequences and then valuing those consequences appropriately against military values are very different exercises. Guidance in this regard from the International Law Commission to establish some common ground upon which environment-military valuations can be compared

consideration and analysis in the present day. This, to Richards and Schmitt represents a clear evolution in the value attributed to the environment over time.

92 Michael N. Schmitt, 'The Principle of Discrimination in 21st Century Warfare' (1999) 2 Yale Human Rights \& Development Law Journal 143, 150-151

${ }^{93}$ Ibid.

${ }^{94}$ Desgagné, fn. 80, 117

95 They are described as heterogenous values by Richards and Schmitt, supra n. 13, at p. 1082

96 Ibid.

${ }^{97}$ Droege and Tougas, supra n. 11, at p. 30 
and balanced would therefore significantly enhance environmental protection through the principle of proportionality. The breadth of the International Law Commission's work on the issue of environmental protection in armed conflict, ${ }^{98}$ drawing upon pre- and post-conflict laws as well as the jus in bello, means that methods of valuing the environment that have been developed in other fields of practice could be identified and adapted to develop guiding principles. At the very least, the International Law Commission could recognise the issue and encourage further work to be done on the valuation of environmental objects during non-international armed conflict. ${ }^{99}$

As it stands, there is no method that can be applied to accurately value the environment in proportionality assessments. In reviewing NATO's bombing campaign against the Federal Republic of Yugoslavia, the ICTY were unable to place a value on the environment that was damaged, asserting instead that at 'a minimum, actions resulting in massive environmental destruction, especially where they do not serve a clear and important military purpose, would be questionable. ${ }^{100}$ The ICTY stated that serious environmental damage could only be justified where a 'very substantial military advantage'101 was achieved. However, devoid of value, it would be impossible to determine whether environmental damage is significant or not. For example, would massive environmental destruction amount to the destruction of an entire rainforest ecosystem? What if

\footnotetext{
${ }^{98}$ International Law Commission, Preliminary Report on the Protection of the Environment in relation to Armed Conflicts, A/CN.4/674 (2014)

${ }^{99}$ Richards and Schmitt, supra n. 13, at p. 1086 argue that 'the existence of differing valuation paradigms, whether temporally, culturally, or contextually determined' directly 'bear on the motivation for valuation' and this will always result in different valuations being used in balancing collateral environmental damage against the value of the military objective being targeted. Such differences, which the authors consider, at p. 1088, to be endemic, will, they feel, always result in inconsistent, unpredictable, and unreliable proportionality calculations. For the reasons stated above, this author disagrees, and asserts that certain ground rules for the valuation of environmental civilian objects can be determined so that some common factors can be established to ensure that a more accurate balancing can occur, which better reflects contemporary environmental values. Emphasis in the past may have been exclusively military objectives and advantages, but that emphasis is no longer reflective of contemporary standards of warfare and the ways in which the laws of armed conflict have been applied.
}

100 ICTY, supra n. 85.

${ }^{101}$ ICTY, supra n. 85 
the last female white rhino became collateral damage in an attack that significantly destabilised enemy forces, shortening the conflict? Would this environmental damage be proportionate to the military advantage gained? The answers depend on how the environment is valued in any given circumstance and principles based on existing international environmental law, or even the dictates of the public conscience, could be developed by the International Law Commission to assist belligerents in making accurate proportionality assessments prior to attack.

\subsection{Introducing Objectivity into Proportionality Assessments of Environmental Collateral}

\section{Damage}

The extent of the collateral damage that can be lawfully caused to the environment currently depends on how it is valued subjectively by belligerents. ${ }^{102}$ Military commanders would not, in general, be considered to be environmental experts with the ability to calculate the true value of an environmental object, and as such, the environment is at risk of being under-valued when proportionality calculations are made. If a subjective point of view is presently determinative when calculating proportionality, then there is currently no incentive for commanders to improve their capacity to value environmental targets. Valuing the environment correctly when calculating proportionality may reduce the options available to the commander when planning attacks. Subjective ignorance of the true value of the environment could actually be militarily advantageous under the principle of proportionality as it is currently interpreted. This under-valuation results in greater collateral damage being allowed than would otherwise be lawful under a more objective or informed calculation.

Moreover, there are certainly unresolved issues regarding the foreseeability of environmental damage in pre-attack proportionality assessments. If environmental damage is unforeseeable then of course it cannot be factored into any test for proportionality that is applied in a given situation.

${ }^{102}$ Schmitt, supra n. 92, 207. See also Richards and Schmitt, supra n. 13, citing Gardam at footnote 166. 
However, foreseeability increases with knowledge, and knowledge about the environment, the effect of harm on certain parts of the environment, the inter-connectedness between ecosystems is improving at a significant rate. ${ }^{103}$ It may be argued that the subjective latitude afforded to commanders on the battlefield is naturally diminishing with increasing global knowledge about the environment and the detrimental effects of certain types of harm. Therefore, in developing guidelines to enhance the protection of the environment in non-international armed conflict, the International Law Commission could usefully consider introducing an objective test for the calculation of proportionality where environmental collateral damage is expected, ${ }^{104}$ based not on the subjective knowledge of the specific commander, but the subjective that a reasonably informed and environmentally-aware commander ought to possess.

While the United Nations Environment Programme claim that '[m]any instances of environmental damage could be seen as a "disproportionate" response to a perceived threat and therefore considered illegal', ${ }^{105}$ this perspective fails to recognise the wholly subjective test that may be applied to evaluate proportionality after an attack has occurred. If the evaluation is based on the subjective knowledge of a specific commander, and if they did not place a high value on the environment in the first place, it is likely that most environmental damage in non-international armed conflict would not be considered disproportionate. Developing principles that insist on a relevant objective test, a test which requires commanders to inform themselves of the types of environmental damage that can occur following certain types of military actions, could incentivise commanders to make proportionality assessments that value the environment appropriately, and

\footnotetext{
${ }^{103}$ Droege and Tougas, supra n. 11, at p. 79.

${ }^{104}$ Bothe, Bruch, Diamond, and Jensen, supra n. 6, argue at p. 578 that expert groups should be convened, potentially resulting in the adoption of resolutions by international organisations to clarifying the principle of proportionality and develop general rules by which environmental damage could be assessed.

105 United Nations Environment Programme, supra n. 5, 13
} 
could greatly increase the degree of protection that can be expected through the principle of proportionality going forward.

\subsection{Conclusion to the Principle of Proportionality}

The principle of proportionality does indeed have the capacity to prevent disproportionate environmental damage in non-international armed conflict from occurring. However, belligerents may find it difficult to value environmental objects appropriately, and then compare that valuation against the advantage to be gained from attacking a specific military objective. Moreover, the degree to which environmental damage is considered to be disproportionate currently depends on the subjective value that is placed on the environment by the specific military commander at the time of an attack. This subjectivity is the Achilles heel of the principle of proportionality as many military commanders may not be equipped with the knowledge to enable them to value the environment appropriately, nor are they incentivised to improve their capacity to do so. Insisting that an objective test is used when environmental collateral damage is being evaluated so that environmental values are properly balanced against anticipated military advantage would significantly improve the power of the principle of proportionality to protect the environment in non-international armed conflict.

\section{The Doctrine of Military Necessity}

The doctrine of military necessity is one of the oldest customary principles in the laws of armed conflict $^{106}$ and it manifests itself on the battlefield in two ways. Both have implications for the protection of the environment in non-international armed conflict. Firstly, the doctrine requires

\footnotetext{
${ }^{106}$ It was first captured in written form during the American Civil War by Francis Lieber in Article 14 of General Orders No. 100 in 1863, often referred to as 'the Lieber Code'. The Lieber code was essentially the first codification of the customary laws of armed conflict, and it was distilled from general principles of human morality, reason and empirical evidence in the form of practice or law. See Burrus M. Carnahan, 'Lincoln, Lieber and the Laws of War: The Origins and Limits of the Principle of Military Necessity’ (1998) 92 American Journal of International Law 213, 213
} 
all acts on the battlefield to be militarily necessary. This means that any damage that is caused to the environment during armed conflict should not be wanton or excessive because to do so would not serve any military purpose. ${ }^{107}$ Secondly, the doctrine permits, in very limited circumstances, the temporary suspension of specific prohibitions within the laws of armed conflict where a military necessity exists. ${ }^{108}$ Although this would appear to permit environmental damage in situations where a military necessity prevails, in practice, the laws of armed conflict do not support this manifestation of the doctrine in non-international armed conflict. However, there appeared to be some uncertainty about the way in which the doctrine of military necessity operated during discussions at the International Law Commission ${ }^{109}$ and so clarification is certainly warranted.

Overall, the doctrine of military necessity, if applied strictly and objectively, can play an important role in protecting the environment during non-international armed conflict. However, critically, the International Law Commission have not engaged in sufficient substantive consideration of military necessity to date. ${ }^{110}$ The following critical analysis may be useful in developing more ambitious and appropriate principles before their current programme of work is concluded.

\subsection{Requirement for Acts to be Militarily Necessary}

In the first instance, the doctrine of military necessity requires all actions taken during armed conflict to be militarily necessary because damage "caused carelessly [is] not "necessary" to the

\footnotetext{
107 Rogers, supra n. 75, 206

108 Hilaire McCoubrey, 'The Nature of the Modern Doctrine of Military Necessity' [1991] The Military Law and Law of War Review 217, 220

109 See International Law Commission, Provisional summary record of the 3264th meeting, supra n. 36, pp. 1, 7, 1415

110 The requirement to adhere to military necessity is included in draft Principle 2, but there is no detail provided on into the manner in which necessity protects the environment or permits damage to it. See International Law Commission, Second Report on the Protection of the Environment in Relation to Armed Conflicts, supra n. 14, 52 \$ 161
} 
achievement of any military purpose. ${ }^{111}$ O' Brien argues that the purpose of military necessity means that there exists 'no equally effective lawful military means, involving less damage or suffering $^{112}$ to achieve the same ends. The necessity does not need to be urgent or imperative, ${ }^{113}$ but it must be supported by circumstances which preclude the pursuit of reasonable alternatives at the time the action is taken. ${ }^{114}$ Therefore any environmental damage that occurs during noninternational armed conflict must not be wanton or careless, but a consequence of the only reasonable actions that could have been pursued at the time the damage occurred. Damage or destruction to the environment in non-international armed conflict must be connected to the pursuit of defeating enemy forces - it cannot be superfluous. ${ }^{115}$ In this way, the contemporary purpose of military necessity has departed significantly from its origins as a rule to trump humanitarian laws which might otherwise prohibit certain conduct. ${ }^{116}$ This is an important point, with provenance in jurisprudence from the IMT at Nuremberg ${ }^{117}$, and certainly worth emphasising in any principles that are developed by the International Law Commission as interpretations to the contrary have begun to emerge in state military manuals. ${ }^{118}$

\footnotetext{
111 Rogers, supra n. 75, 206

112 William V. O' Brien, 'The Meaning of "Military Necessity" in International Law' (1957) 1 World Polity 109, 141

113 Ibid., pp. 138-139. Though necessity will indeed frequently be immediate: McCoubrey, supra n. 108, 239

114 McCoubrey, supra n. 108, 226

${ }^{115}$ Hulme, supra n. 30, pp. 212-213

116 Betsy Baker, 'Legal Protections for the Environment in Times of Armed Conflict', (1993) 33 Virginia Journal of International Law 351, at p. 360 and at footnote 43 citing McCoubrey. See also Richards and Schmitt, supra n. 13, at p. 1076

117 Hulme, supra n. 30, at p. 213

118 International Committee of the Red Cross, Customary Law Database, Practice Relating to Rule $43<$ https://ihldatabases.icrc.org/customary-ihl/eng/docs/v2_rul_rule43> (accessed 11 March 2019)
} 
Military necessity was used to justify environmental damage caused during the Second World War in the The Hostages Trial $^{119}$ at the International Military Tribunal at Nuremberg. In this case, General Lothar Rendulic argued that the scorched earth policy implemented during the German retreat from Finnmark was required by military necessities that existed at the time. The Tribunal held that although the necessity in retrospect did not exist, and viewed with hindsight the damage caused was indeed superfluous, there was sufficient subjective necessity at the time of the actions, even though General Rendulic was mistaken in believing that his forces were in jeopardy of imminent attack, to justify the environmental damage. ${ }^{120}$

The subjective perspective of the commander at the time the destruction occurs continues to be determinative of whether environmental damage is justified by military necessity or superfluous, as the Office of the Prosecutor at the ICTY endorsed it as a legitimate precedent for any similar future case. ${ }^{121}$ Yet the subjective test significantly decreases the positive effect that military necessity can have in prohibiting unnecessary environmental damage during non-international armed conflict since mistaken beliefs, if reasonably and honestly held, would be enough to satisfy the requirements of the doctrine in relation to most environmental damage resulting from a course of action during armed conflict. To improve environmental protection under this application of the doctrine of military necessity, future principles that are developed should challenge this perspective and insist that an objective test be used to ensure that environmental damage in noninternational armed conflict is clearly militarily necessary and not superfluous or wanton.

\subsection{Suspension of the Laws of Armed Conflict due to Military Necessity}

\footnotetext{
119 Wilhelm List and Others (The Hostages Trial) (1949) Law Reports of Trials of War Criminals Selected and Prepared by the United Nations War Crimes Committee Vol VIII 34

${ }^{120}$ See Brian J. Bill, 'The Rendulic “Rule”: Military Necessity, Commander's Knowledge, and Methods of Warfare' 12 Yearbook of International Humanitarian Law 119 (2009)

${ }^{121}$ ICTY, supra n. 85, \ 23
} 
During the American Civil War, it was felt that military necessity had the potential to become a 'rule-swallowing' norm and so the doctrine was, at the time, very narrowly construed. ${ }^{122}$ However fears about the doctrine subverting the laws of armed conflict were borne out in mid- $19^{\text {th }}$ century Germany when the doctrine became the "bete noir" ${ }^{123}$ of international law under the maxim Kriegsraison geht vor Kriegsmanier - the necessities of war take precedence over the rules of war. ${ }^{124}$ This interpretation of military necessity permitted 'the commander on the battlefield [to] decide in every case whether the rules will be respected or ignored, depending on the demands of the military situation at the time. ${ }^{125}$ The International Military Tribunal at Nuremberg, condemned the kriegsraison theory of military necessity during The Hostages Trial ${ }^{126}$ when they indicated quite clearly that 'military necessity or expediency [does] not justify a violation of positive rules. ${ }^{, 27}$ Military necessity now remains subordinate to the laws of armed conflict at all times. ${ }^{128}$ Fears that military necessity permits 'uncontrolled brute force to rage rampant over the battlefield or wherever the military have control ${ }^{129}$ are no longer supported by contemporary interpretations of the laws of armed conflict. Despite the perception that military necessity sometimes appears to justify 'acts

\footnotetext{
${ }^{122}$ Scott Horton, 'Kriegsraison or Military Necessity? The Bush Administration's Wilhelmine Attitude Towards the Conduct of War' (2006-2007) 30 Fordham International Law Journal 576, 580

${ }^{123}$ William Gerald Downey Jr, 'The Law of War and Military Necessity' (1953) 47 American Journal of International Law 251, 251

124 Yves Sandoz, Christophe Swinarski and Bruno Zimmermann (eds.), Commentary on the Additional Protocols of 8 June 1977 to the Geneva Conventions of 12 August 1949 (Martinus Nijhoff Publishers 1987), 391

125 Ibid.

126 Wilhelm List and Others (The Hostages Trial), supra n. 119, 66. Kriegsraison has now been fully 'discredited': See Sandoz, Swinarski, and Zimmermann supra n. 124, p. 391. It has no place in the modern laws of armed conflict: O' Brien, supra n. 112, 129

${ }^{127}$ Wilhelm List and Others (The Hostages Trial), supra n. 119, 66

${ }^{128}$ Rogers, supra n. 75, 206

${ }^{129}$ Downey, supra n. 123 , p. 251
} 
of dubious legality, normality, and utility ${ }^{130}$, the doctrine remains fundamentally subject to the laws of armed conflict, rather than as a blanket exception to them. ${ }^{131}$ Arguments in favour of this interpretation refer to the fact that contemporary laws of armed conflict were drafted with the exigencies of military necessity in mind, and provision was explicitly provided for military necessity in relation to some limited treaty-based laws of armed conflict, and not provided in relation to the vast majority of others. ${ }^{132}$

For example, Art. 54(5) of Additional Protocol I permits derogation from the prohibition against targeting objects indispensable to the survival of the civilian population in international armed conflict 'where required by imperative military necessity'. ${ }^{133}$ However the comparable provision in Additional Protocol II, which applies to non-international armed conflict, contains no such permission to derogate. Therefore, even where a compelling military necessity exists, the protection granted by Article 14 of Additional Protocol II is absolute. The prohibition against pillage in Article 4(2)(g) of Additional Protocol II provides another good example of this point. This provision is frequently raised as a means of prohibiting wanton damage to and looting of natural resources during the conduct of hostilities. ${ }^{134}$ Article $4(2)(\mathrm{g})$ contains no clause which carves out an exception for situations of military necessity and as such, military necessity could not be used to justify pillage of natural resources in non-international armed conflict. Indeed, no treatybased provisions that are relevant to environmental protection in non-international armed conflict

\footnotetext{
130 O' Brien, supra n. 112, pp. 173-174

${ }^{131}$ Horton, supra n. 122, 580

132 Baker, supra n. 116, at pp. 362-363

133 Additional Protocol I, supra n. 3, Art. 54(5). While the necessity may indeed continue to exist 'over an extended period' of time, once the period of military necessity is over, 'compliance with legal provisions must be resumed': McCoubrey, supra n. 108, 239

134 Daniella Dam-de Jong, 'International Law and Resource Plunder: The Protection of Natural Resources during Armed Conflict' (2008) 19 Yearbook of International Environmental Law 27, 28
} 
contain clauses which permit derogations required by military necessity. ${ }^{135}$ It is quite clear that military necessary could not be used to justify environmental damage in non-international armed conflict if such damage otherwise breached existing treaty-based or customary laws armed conflict.

However, worryingly, the ICRC have concluded, on the basis of state practice and opinio juris drawn from a very small number of states ${ }^{136}$ that customary international law permits the destruction of the environment in non-international armed conflict if justified by military necessity. ${ }^{137}$ The ICRC have suggested that 'destruction of any part of the natural environment is prohibited, unless required by imperative military necessity. ${ }^{138}$ Although this is fundamentally at odds with a correct application of the law, left unaddressed it may in time reverse the subordinate position of military necessity and reinstate a kriegraison-style norm as the dominant rule. The law is clear at present: military necessity cannot be used to justify a violation of the laws of armed conflict unless it is

${ }^{135}$ For example see Additional Protocol II, supra n. 43, Arts. 4(2)(g), 13, 14, 15, 16 and 17

136 See for example military manuals, legislation and statements of Australia, United Kingdom, United States if America, Nicaragua, Spain and Iran in the ICRC's Customary Law Database <https://ihldatabases.icrc.org/customary-ihl/eng/docs/v2_rul_rule43> accessed 19 February 2019. Collectively this state practice is insufficient to support the conclusion that this interpretation of the application of military necessity to conduct that harms the environment in non-international armed conflict. Some authoritative statements representing the collective views of states, for example in UN General Assembly Resolution 47/37 of 25 November 1992, are used by the ICRC to support their conclusion that military necessity can justify the destruction of the environment in noninternational armed conflict under customary international law. However statements such as that contained in the UN General Assembly Resolution just cited, do not preclude an interpretation of the law as provided in this article, namely that military necessity cannot be used to justify a breach of the laws of armed conflict unless specifically provided for in the context of a particular treaty rule or customary law. For example, the preambular statement in the aforementioned UN General Assembly Resolution stresses that 'destruction of the environment, not justified by military necessity and carried out wantonly, is clearly contrary to existing international law'. This statement is certainly legally accurate, as it is argued in this article that destruction of the environment in non-international armed conflict, both justified and not justified by military necessity, is a breach of the laws of armed conflict unless the environment that is targeted can be classified as a military objective and conforms to the principle of proportionality. The ICRC's representation of state practice and opinio juris in Rule 43(B) of the Customary Law Study has been criticised by Hulme, supra n. 30 at p. 212, as not accurately representing the law as it suggests that customary international law required 'imperative' military necessity, when such an assertion is not supported by the evidence. In all, Rule 43(B) as formulated seems to be quite problematic and may be in danger of misrepresenting the law to parties not inclined to follow up a reading of the rule with an examination of the practice. The International Law Commission should not reflect the ICRC's statement in any principles that are drafted. Rule 43(B) has also been criticised by Fleck, supra n. 82 , who has argued at p. 13 that it 'is to be applied with caution. It should not be taken as justifying attacks against civilian objects as a matter of military necessity.'

137 ICRC, Customary IHL Database, Rule 43(B) < https://ihl-databases.icrc.org/customaryihl/eng/docs/v1_rul_rule43> accessed 8 March 2018.

138 Ibid. 
'explicitly provided for by the rule in question'. ${ }^{139}$ The International Law Commission should unequivocally affirm the subordinate status of the doctrine of military necessity in any principles that are developed to ensure that any environmental protection that indirectly results from the treaty-based or customary laws of non-international armed conflict is not undermined.

\subsection{Conclusion to Military Necessity}

It is clear that military necessity may only be used to justify a breach of the laws of armed conflict if such an exception is explicitly included in the text of a particular treaty-provision or is inherently part of a customary rule. As Hulme surmises, 'the doctrine of military necessity has become a limited one, active only where sanctioned within the law itself. ${ }^{140}$ In this regard, military necessity does not undermine existing treaty or customary law that provides indirect protection to the environment in non-international armed conflict as the treaty-based rules in Common Article 3 and Additional Protocol II have no associated military necessity clause, and the principles of distinction and proportionality cannot be suspended if an overriding military necessity exists. However, the subjective test for military necessity that is used to assess general environmental damage that occurs on the battlefield weakens the overall level of protection that this customary principle can deliver and there is an imperative need to introduce some degree of objectivity into applications of the doctrine of military necessity going forward.

\footnotetext{
${ }^{139}$ Sandoz, Swinarski and Zimmermann, supra n. 124, p. 391. See also M. Greenspan, The Modern Law of Land Warfare (University of California Press 1959), 314 as cited in McCoubrey, supra n. 108, 221: 'In fact the rules of war make allowance within their framework for military necessity, which cannot transcend the rules themselves...[M]ilitary necessity was...taken into account when the rules were framed, and the individual rules themselves indicate to what extent they may be modified under the stress of military necessity.' The drafters of the laws of armed conflict have consciously connected military necessity exceptions to some rules and consciously omitted them as against others. O' Brien, supra n. 112, 131 - 'international lawyers could refute any claim of a general exception of military necessity by pointing out that legitimate exceptions of this kind had already been provided.' Indeed the drafters of the San Remo Manual on Non-International Armed Conflict have concluded that 'the extensive codification of the jus in bello, [means that] the principle of military necessity has little practical bearing on the conduct of hostilities except insofar as it is retained in treaty form in specific situations.' International Institute of Humanitarian Law, The Manual on the Law of Non-International Armed Conflict with Commntary, San Remo 2006, 10
}

${ }^{140}$ Hulme, supra n. 84, 131 


\section{Conclusion}

The main objective of this article was to fill key knowledge gaps regarding the protection of the environment in non-international armed conflict through customary international law and in so doing, highlight crucial issues that the international community has an unprecedented opportunity to address as part of the International Law Commission's ongoing work. The approach to enhancing environmental protection in non-international armed conflict presented in this article avoiding insurmountable issues regarding the development of new law by progressively and purposively interpreting existing law - has significant potential. It is hoped that the proposals that have been suggested in the analysis above can provide grounds for discussions at the International Law Commission to develop more detailed principles and guidelines which meaningfully improve environmental protection in non-international armed conflict going forward.

In this article, it was demonstrated that the established customary international law principles of distinction, proportionality, and military necessity can each play a better role in enhancing protection of the environment during non-international armed conflict. Progressive interpretations of each customary law, if developed and incorporated into principles by the International Law Commission, would constitute a significant advancement in the legal protection of the environment during non-international armed conflict.

Regarding the principle of distinction, it was argued that a mere restatement of the principle is unlikely to improve environmental protection in future non-international armed conflicts. Instead, clarification that the environment as a whole might be considered a civilian object which cannot be directly attacked, and narrowly construing the circumstances in which the environment can be classified as a military objective, would serve to better improve environmental protection under this principle. While dual-use objects present particularly difficult issues, asserting that some specific environmental objects - those that are of special significance or which contribute to the 
solution of global challenges - can never be classified as military objectives would enhance environmental protection in non-international armed conflict where it is arguably needed most.

While the principle of proportionality appears to require a straightforward balance between the value of attacking a military objective and the expected resulting collateral damage to civilians and civilian objects, it was argued that valuing environmental civilian objects correctly is not always achieved when this principle is applied in practice. This is due to the inherent subjectivity within the principle, which regards a commander's subjective valuation of civilian environmental objects as definitive. As a result, environmental civilian objects are frequently under-valued, and therefore at risk of greater collateral damage when attacks are being planned and implemented. This article proposes that the subjective valuation of environmental civilian objects be replaced by an understanding which requires objective valuations of the environment to be factored into proportionality assessments. This would allow a more appropriate value to be assigned to environmental civilian objects, thereby decreasing the risk of undervaluation and the objectively disproportionate harm that can follow. Such an understanding would ensure that any collateral damage that is caused to the environment is minimised as far as possible under the circumstances, which the entire purpose of the principle of proportionality.

It was asserted that the doctrine of military necessity can play a significant role in protecting the environment in non-international armed conflict. It requires all actions taken during armed conflict and all damage to be militarily necessary, and so if damage to the environment is not militarily necessary under the circumstances, then it is not permitted. However, at present, a subjective test is used to assess necessity on the battlefield, and it was argued that this ought to be replaced by an objective test when it comes to determining that environmental damage is militarily necessary. Moreover, while the doctrine of military necessity may permit derogations from specific laws of armed conflict, none of the laws of armed conflict that apply during non-international armed conflict to indirectly protect the environment contain such an exception. Acknowledging this in 
any development of the law that follows the International Law Commission's examination of the issue would provide much-needed clarity and improved environmental protection on the battlefield.

While the customary international laws of distinction, proportionality and necessity can be harnessed to deliver better environmental protection in non-international armed conflict, that enhanced protection will only take place if the parameters and the potential of these customary rules are fully and strategically embraced by states and the wider international community. The International Law Commission's programme of work on environmental protection in armed conflict is an ideal place to begin such ground-breaking changes in the way the law is interpreted and applied, and for novel interpretations of existing law to be shaped. While the draft principles that are presently under consideration by the International Law Commission do little more than refer to existing law, and as such do little to enhance environmental protection, this article demonstrates that there is significant potential for more ambitious proposals to be made to enhance environmental protection in non-international armed conflict going forward. 